\title{
Differential proteomic and phenotypic behaviour of papillary and anaplastic thyroid cell linesis
}

\author{
Rosa Musso ${ }^{a}$, Gianluca Di Cara ${ }^{a}$, Nadia Ninfa Albanese $e^{a, d}$, Maria Rita Marabeti ${ }^{a}$, \\ Patrizia Cancemi ${ }^{a, c}$, Dèsirèe Martini ${ }^{e}$, Ester Orsini $^{e}$, Carla Giordano ${ }^{a, b}$, Ida Pucci-Minafra ${ }^{a, *}$ \\ ${ }^{a}$ Center of Experimental Oncobiology (C.OB.S.), "La Maddalena” Hospital III Level Oncological Dept., Palermo, Italy

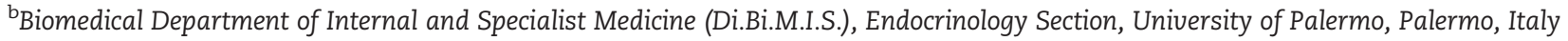 \\ ${ }^{c}$ Department of Molecular and Biomolecular Science and Technology (STEMBIO), University of Palermo, Palermo, Italy \\ dDepartment of Physics and Chemistry, University of Palermo, Palermo, Italy \\ e Department of Human Anatomical Sciences and Physiopathology of Locomotor Apparatus, Human Anatomy Section, \\ University of Bologna, Bologna, Italy
}

\section{A R T I C L E I N F O}

Article history:

Received 17 November 2012

Accepted 22 January 2013

Keywords:

Thyroid cancer

Papillary

Anaplastic

BCPAP cells

$8505 \mathrm{C}$ cells

Proteomics

\begin{abstract}
A B S T R A C T
Thyroid carcinomas account for a minority of all malignant tumours but, after those of the gonads, they represent the most common forms of endocrine cancers. They include several types, among which the papillary thyroid cancer (PTC) and the anaplastic thyroid cancer (ATC) are the best known. The two hystotypes display significant biological and clinical differences: PTC is a well differentiated form of tumour with a high incidence and a good prognosis, while the ATC is less frequent but represents one of the most aggressive endocrine tumours with morphological features of an undifferentiated type. To date, as far as we know, no conclusive studies, useful to design arrays of molecular markers, have been published illustrating the phenotypic and proteomic differences between these two tumours. The aim of this work was to perform a comparative analysis of two thyroid cancer cell lines, derived respectively from papillary (BCPAP) and anaplastic (8505C) thyroid carcinomas. The comparative analysis included cell behaviour assays and proteomic analysis by 2D-PAGE and mass spectrometry. The results have highlighted a new proteomic signature for the anaplastic carcinoma-derived cells, consistent with their high proliferation rate, motility propensity and metabolic shift, in relation to the well-differentiated PTC cells.

This article is part of a Special Issue entitled: From Genome to Proteome: Open Innovations.
\end{abstract} (C) 2013 Published by Elsevier B.V.

\section{Introduction}

The human thyroid gland is composed of a basic structural unit, the follicle, consisting of a monolayer of well polarized cells, the thyrocytes, responsible for the T3/T4 hormone secretion, and of other peripheral cells, the parafollicular $C$ cells, responsible for the secretion of calcitonin. The presence within the follicle of stem cells, or remnants of embryonic cells, has been hypothesized as the target cells for tumour initiation. A thin extracellular matrix, which includes occasional fibroblasts and inflammatory cells, is peripheral to the follicle structure.

Thyroid carcinomas account for $1-2 \%$ of all malignant tumours and, after those of the gonads, they represent the most common tumours of the endocrine system. The thyroid

ts This article is part of a Special Issue entitled: From Genome to Proteome: Open Innovations.

* Corresponding author at: Center of Experimental Oncobiology (C.OB.S.), "La Maddalena" Hospital III Level Oncological Dept., Via San Lorenzo Colli 112d, 90146 Palermo, Italy. Tel.: +39 0916806418; fax: + 390916806418.

E-mail address: ida.pucci@unipa.it (I. Pucci-Minafra).

1874-3919/\$ - see front matter @ 2013 Published by Elsevier B.V. http://dx.doi.org/10.1016/j.jprot.2013.01.023 
tumours include several histotypes with different molecular profiles, as well as biological and clinical behaviours.

Among these, papillary (PTC) and anaplastic (ATC) histotypes are probably the most investigated. The two hystotypes display significant phenotypic differences, as well as dissimilar clinical occurrences and outcomes. Indeed, PTC is a well differentiated form of tumour with a high incidence, representing approximately $80 \%$ of all thyroid tumours and is characterized by a good prognosis [1]. On the contrary, ATC accounts for less than 5\%, but it is one of the most aggressive endocrine tumours with morphological features of an undifferentiated type.

However, to date no studies have definitely demonstrated whether malignant forms of thyroid tumours arise from the adult epithelial cells through multistep cancerogenesis [2] or from remnants of foetal thyroid cells [3] or, as more recently hypothesized, from resident stem cells [4-6].

Many genetic alterations have been described as involved in the progression, mostly leading to the anomalous activation of the MAP kinase pathway. Several studies have suggested that BRAF $^{(\mathrm{V} 600 \mathrm{E})}$ mutation (90\% of all BRAF mutations) plays an important role in the early steps of the thyroid carcinogenesis leading to the progression towards the anaplastic forms [7-10], but some controversies about its significance still remain.

Therefore, the biological mechanisms of thyroid cancerogenesis are still unclear. This is also because the panels of putative biomarkers for thyroid cancer histotypes are not yet adequate enough to fulfil the requirements for molecular diagnosis, prognosis and target therapy. We suggest that the increase in knowledge of protein expression in thyroid tumours, as for the breast cancer [11-13], could greatly help to understand molecular mechanisms involved in the thyroid carcinogenesis. With this aim, we performed a comparative analysis of two thyroid cancer cell lines, derived respectively from papillary (BCPAP) and anaplastic (8505C) thyroid carcinomas. The comparative analysis included cell behaviour assays, proteomic analysis by 2D-PAGE and mass spectrometry.

First of all, in this study we show that both PTC and ATC cell lines closely maintain in vitro phenotypical characteristics, probably resembling their in vivo counterparts. Indeed, the 8505C cells are characterized by cell traits and a behaviour typical of the aggressive phenotype associated with an advanced stage of the disease. On the contrary, the BCPAP cells derived from a more differentiated tumour, maintain in vitro a rather stable phenotype and the ability to reorganize "follicle-like" structures. Our findings confirm that these cell lines represent an important model for the in vitro study of differentiated and undifferentiated thyroid tumours and may offer new insights into the thyroid carcinogenesis. The proteomic study revealed a panel of differentially expressed proteins, instrumental for cancer growth and invasion, which may be used for future applications as biomarkers of thyroid malignancy.

\section{Materials and methods}

\subsection{Cell culture}

The human papillary thyroid carcinoma cell line, BCPAP established in 1992 [14] and human anaplastic thyroid carcinoma cell line, 8505C established in 1994 [15] were provided by the Endocrinolgy Labolatory of Prof. C. Giordano. Cells were seeded at a density of $10^{4}$ cells $/ \mathrm{cm}^{2}$ and grown in RPMI 1640 (GIBCO), supplemented with 10\% foetal bovine serum (GIBCO), 1\% L-glutamine, $1 \%$ penicillin and $1 \%$ streptomycin in a humidified incubator with $5 \% \mathrm{CO}_{2}$ in air at $37^{\circ} \mathrm{C}$.

\subsubsection{Cell proliferation}

The assay [16] was performed by the use of a colorimetric tetrazolium compound (CellTiter 96, Promega). Briefly, $20 \mu \mathrm{l}$ of CellTiter 96 was added to $100 \mu$ l of medium into each well containing the cells. After $1 \mathrm{~h}$ of incubation in a humidified $5 \%$ $\mathrm{CO}_{2}$ atmosphere, the absorbance at $492 \mathrm{~nm}$ was read using a 96-well plate reader (Amersham).

\subsubsection{Scratch assay}

The confluent mono-layers of BCPAP and $8505 \mathrm{C}$ cells were scraped with a p200 pipet tip. Following the "scratch", the cells debris were removed by several washes with phosphatebuffered saline (PBS) and fresh growth medium was added. The assays were monitored at different times (6 h-24 h) through optical microscopy.

\subsection{Gelatin zymography}

\subsubsection{Conditioned media preparations}

Conditioned media of BCPAP and 8505C confluent cells were collected after $24 \mathrm{~h}$ of culture in absence of serum. The media were then submitted to extensive dialysis against ultrapure distilled water at $4{ }^{\circ} \mathrm{C}$ and lyophilized. Dried samples were solubilized in a buffer $50 \mathrm{mM}$ Tris-HCl, pH 7.5.

\subsubsection{Zymograpic assay}

Aliquots corresponding to $10 \mu \mathrm{g}$ were used for monodimensional gelatin zymography, that was performed under non-reducing conditions, on 7.5\% SDS-PAGE copolymerized with $0.1 \%$ gelatin, using a minigel lab apparatus (Biorad). Following the electrophoresis, the SDS was removed from the gel by washes of $1 \mathrm{~h}$ with $2.5 \%$ Triton-X 100 in $50 \mathrm{mM}$ Tris- $\mathrm{HCl}$, $\mathrm{pH}$ 7.5. The zymogram was subsequently developed for $18 \mathrm{~h}$ at $37^{\circ} \mathrm{C}$ in a buffer containing $50 \mathrm{mM}$ Tris-HCl, pH 7.5, 0.15 $\mathrm{M} \mathrm{NaCl}$ and $10 \mathrm{mM} \mathrm{CaCl}_{2}$ [17]. Gel was stained with Coomassie blue and unstained areas corresponding to zones of digestion were visualized after destaining with $7 \%$ methanol in $5 \%$ acetic acid.

\subsubsection{Western blotting}

Zymographic controls were performed by western blot assay with purified samples of proMMP-2 and proMMP-9 (kindly donated by Dr H. Nagase, Imperial College, UK), probed respectively with one of the two monoclonal antibody: anti-MMP-2 mouse mAb (1:1000; Santa Cruz, Heidelberg, Germany) and antiMMP-9 mouse mAb (1:1000; Santa Cruz). Following incubation with the appropriate peroxidase-linked antibody [horseradish peroxidase-conjugated goat anti-mouse IgG (1:3000; Santa Cruz)], the reaction was revealed by the ECL detection system, using high performance films (Hyperfilm ECL; Amersham).

\subsection{Scanning electron microscopy (SEM)}

BCPAP and 8505C cells were seeded in T-25 cell culture flasks at a concentration of $15 \times 10^{3} \mathrm{cell} / \mathrm{cm}^{2}$ and were processed for 
SEM observation, performed at the Human Anatomy Section, University of Bologna, Italy. The cell culture flasks were carefully rinsed with PBS to prevent the cells detachment. Cells were fixed with Karnowski solution (1.5\% glutaraldehyde, $1 \%$ paraformaldehyde, $1 \%$ cacodylate buffer, $\mathrm{pH} 7.4$ ) for $10 \mathrm{~min}$. Flasks with adhering cells were then rinsed three times with $0.1 \%$ cacodylate buffer, postfixed for 20 min with $1 \% \mathrm{OsO}_{4}$ in cacodylate buffer, dehydrated with ethanol, and finally dried with hexamethyldisilazane (Sigma) for $15 \mathrm{~min}$, as described [18]. Then the specimens were coated with $20 \mathrm{~nm}$-thick palladium-gold film and examined using a Philips SEM 515 at $15 \mathrm{kV}$.

\subsection{Two dimensional gel electrophoresis}

\subsubsection{Sample preparations}

Cells were grown in the presence of serum until $80-90 \%$ confluence, then they were serum starved for $24 \mathrm{~h}$, harvested with cell scraper in PBS and lysed in M-RIPA buffer $(50 \mathrm{mM}$ Tris $\mathrm{pH} 7.5,0.1 \%$ Nonidet P-40, 0.1\% deoxycholate, $150 \mathrm{mM}$ $\mathrm{NaCl}, 4 \mathrm{mM}$ EDTA) added with a mixture of protease inhibitors (0.01\% aprotinin, $10 \mathrm{mM}$ sodium pyrophosphate, $2 \mathrm{mM}$ sodium orthovanadate, $1 \mathrm{mM}$ PMSF). The whole cellular lysate was centrifuged at $14,000 \mathrm{rpm}$ for $8 \mathrm{~min}$ to clear cell debris and stored at $-80{ }^{\circ} \mathrm{C}$. Protein concentration in the cellular extracts was determined using the Bradford method [19].

\subsubsection{D-IPG}

Cell lysates of BCPAP and $8505 \mathrm{C}$ cells were submitted to extensive dialysis against ultrapure distilled water at $4{ }^{\circ} \mathrm{C}$ and lyophilized. Dried samples were solubilized in a buffer containing $4 \%$ 3-[(3-cholamidopropyl)dimethylammonio]-1-propanesulfonate (CHAPS), 40 mM Tris, 65 mM 1, 4 dithioerythritol (DTE) and a trace of bromophenol blue in $8 \mathrm{M}$ urea. Aliquots of $45 \mu \mathrm{g}$ (analytical gels) or $1.5 \mathrm{mg}$ (preparative gels) of total proteins were separately mixed with $350 \mu$ l of rehydration solution containing $8 \mathrm{M}$ urea, 2\% CHAPS, $10 \mathrm{mM}$ DTE and 0.5\% carrier ampholytes (Resolyte 3.5-10; Amersham), and applied for isoelectrofocusing (IEF) using commercial sigmoidal IPG strips, $18 \mathrm{~cm}$ long with pH range 3.0-10; (Bio-rad, Segrate, Milano, Italy). The IEF was carried out by linearly increasing the voltage from 200 to $3500 \mathrm{~V}$ during the first $3 \mathrm{~h}$, after which focusing was continued at $8000 \mathrm{~V}$ for $8 \mathrm{~h}$. After the run the IPG strips were equilibrated with a solution containing $6 \mathrm{M}$ urea, 30\% glycerol, $2 \%$ Sodium Dodecyl Sulphate (SDS), 0.05 M Tris-HCl, pH 6.8 and $2 \%$ DTE for $12 \mathrm{~min}$, in order to re-solubilize the proteins and reduce the disulphuric bonds. The-SH groups were then blocked by substituting the DTE with $2.5 \%$ iodoacetamide in the equilibrating buffer. The focused proteins were then separated on 9-16\% linear gradient polyacrylamide gels (SDS-PAGE) with a constant current of $20 \mathrm{~mA} / \mathrm{gel}$ at $10{ }^{\circ} \mathrm{C}$ and the separated proteins were visualized by ammoniacal silver staining [20].

\subsubsection{Image acquisition and data analysis}

Silver-stained gels were digitized using a computing densitometer and analyzed with ImageMaster 2D PLATINUM software (Amersham Biosciences, Sweden). Gel calibration was carried out using an internal standard and the support of the ExPaSy molecular biology server, as described elsewhere [21]. Quantitative variations in the protein expression levels were calculated as the volume of the spots (i.e. integration of optical density over the spot area). In order to correct for differences in gel staining, the spot volumes relative to the sum of the volume of all spots on each gel (\%Vol) were calculated by the software.

\subsection{Protein identification}

\subsubsection{N-Terminal microsequencing}

It was performed by automated Edman degradation in a protein sequencer (Procise 419; Applied Biosystems), as previously described [22].

\subsubsection{In-gel digestion and MALDI-TOF analysis}

Mass spectrometric sequencing was performed with the Voyager DE-PRO (Applied Biosystems) mass spectrometer as described elsewhere [12]. Briefly, proteins were digested using sequencinggrade trypsin $(20 \mu \mathrm{g} / \mathrm{vial})$. The tryptic peptide extracts were dried and re-dissolved in $10 \mu \mathrm{l}$ of $0.1 \%$ trifluoroacetic acid (TFA). The matrix, R-cyano-4-hydroxycinnamic acid (HCCA), was purchased from Sigma-Aldrich. A saturated solution of HCCA (1 $\mu \mathrm{l})$ at $2 \mathrm{mg} / 200 \mu \mathrm{l}$ in $\mathrm{CH}_{3} \mathrm{CN} / \mathrm{H}_{2} \mathrm{O}(50: 50 \mathrm{v} / \mathrm{v})$ containing 0.1\% TFA was mixed with $1 \mu \mathrm{l}$ of peptide solution on the MALDI plate and left to dry. MALDI-TOF mass spectra were recorded in the 500-5000 Da mass range, using a minimum of 100 shots of laser per spectrum. Delayed extraction source and reflector equipment allowed sufficient resolution to consider $\mathrm{MH} \pm$ of monoisotopic peptide masses. Internal calibration was carried out using trypsin autolysis fragments at $\mathrm{m} / \mathrm{z} 842.5100,1045.5642$, and 2211.1046 Da. Peptide mass fingerprinting was compared to the theoretical masses from the Swiss-Prot or NCBI sequence databases using Mascot (http://www.matrixscience.com/). Typical search parameters were as follows: $50 \mathrm{ppm}$ of mass tolerance, carbamidomethylation of cysteine residues, one missed enzymatic cleavage for trypsin, a minimum of four peptide mass hits was required for a match, methionine residues could be considered in oxidized form.

\section{Results}

\subsection{Cell morphology}

Fig. 1 shows the representative optical and scanning electron micrographs of BCPAP and 8505C cells. BCPAP cells (Fig. 1(A)) grow in monolayer and exhibit a roughly uniform size with an apparent smooth regular surface, which at SEM (Fig. 1(C)) appears decorated by short microvillous expansions.

At sub-confluence most of the cells produce circular structures of variable size (Fig. 1(A)), often delimiting small central cavities, probably corresponding to the "holes" described by Fabien et al. [23], which mimic the thyroid follicles. In contrast, the $8505 \mathrm{C}$ cells manifest very irregular cellular shapes, sizes and contours. They show a tendency to overgrow in multilayer and to produce long cell surface protrusions of variable size, observable at both optical (Fig. 1(B)) and scanning microscopy (Fig. 1(D)).

\subsection{Cell proliferation}

Fig. 2 shows the growth curves of BCPAP and 8505C cells where each point represents the mean of three replicates 

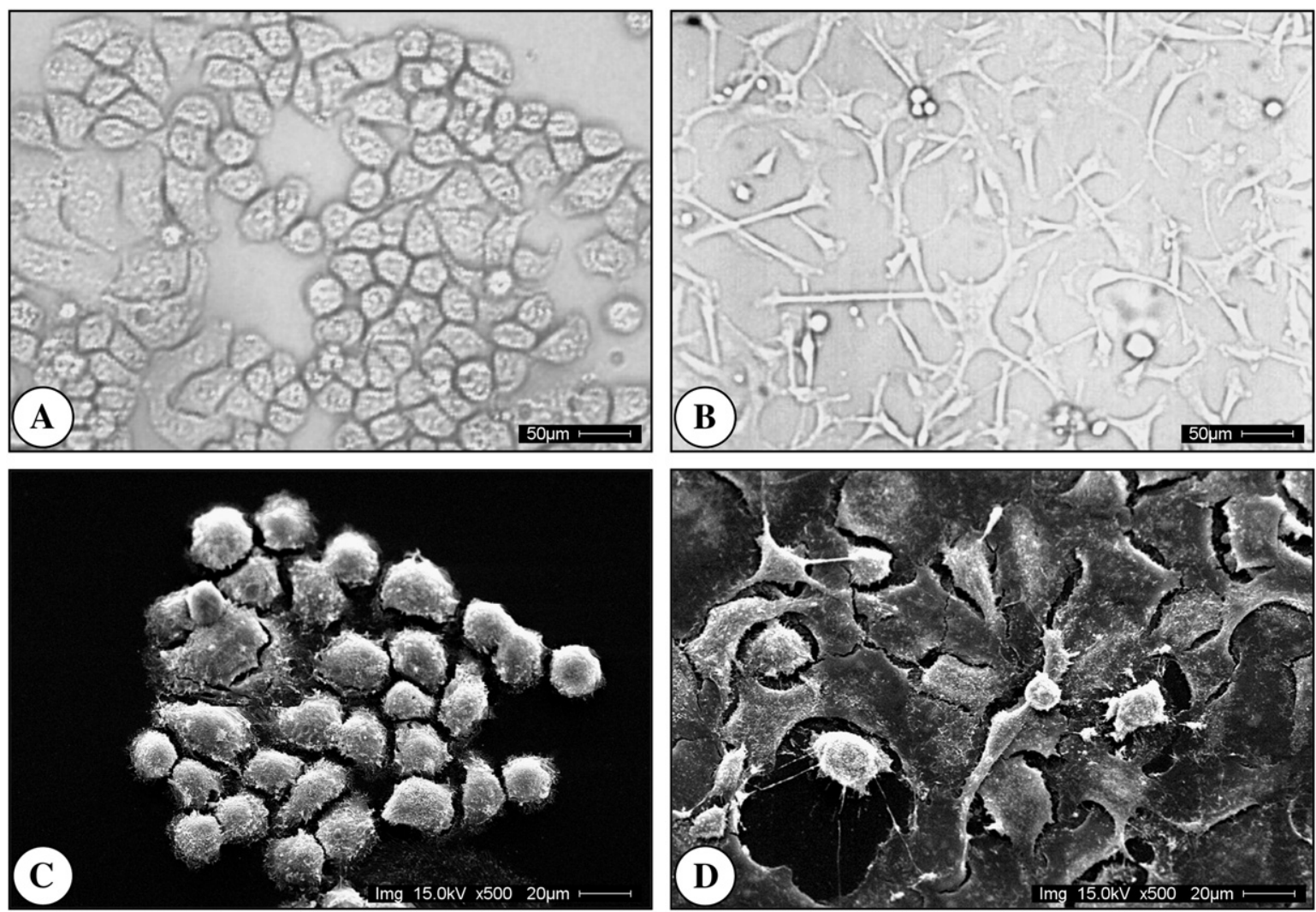

Fig. 1 - Representative micrographs of BCPAP and 8505C cells. The figure shows the optical micrographs: A) BCPAP; B) 8505C (magnification: 20x); and scanning electron micrographs: C) BCPAP; D) 8505C (magnification: 500x).

from three independent experiments $( \pm \mathrm{SD})$. Cell proliferation was evaluated every day from the first $24 \mathrm{~h}$ until 9 days after seeding. As can be observed, the difference in cell proliferation between the two cell lines is evident at 4 days from seeding, where the cell density of $8505 \mathrm{C}$ cell line is $\sim 30 \%$ higher with respect to B-CPAP cell line. From the 7th day on, this difference is significantly reduced in conjunction with the cellular over-confluence decay of both cell lines.

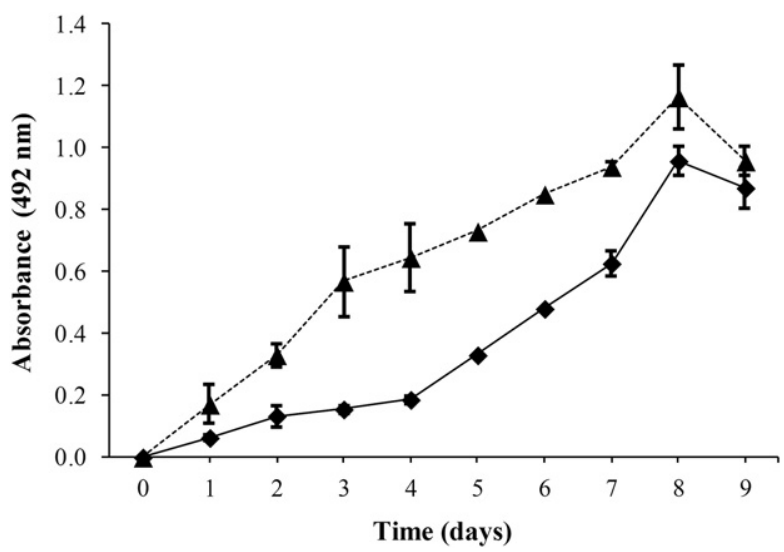

Fig. 2 - Proliferation assay of thyroid cancer cells at different times. Diagram illustrates the growth rate of BCPAP (continuous line) and 8505C (dotted line) cells, by using the MTS colorimetric assay.

\subsection{Proteomic analysis}

Representative 2D proteomic maps of BCPAP and 8505C cells are shown in Fig. 3. The protein identities are marked with labels corresponding to the accession numbers of the SwissProt database and the different isoforms of the same protein are jointly labelled.

In the present study we have identified 223 protein forms, corresponding to 147 genes, by MALDI-TOF and/or N terminal sequencing (for more details see the Supplementary Table with the catalogue of identified proteins).

For the comparative analysis of protein expression, the average of three spot values from three different BCPAP and $8505 \mathrm{C}$ cells gels was utilized (Fig. 4) and protein levels were considered significantly different for $\geq 2$-fold variation (Fig. 5). Out of the 223 identified proteins, 63 protein forms, corresponding to 50 genes, were found to be differentially expressed in $8505 \mathrm{C}$ in comparison with BCPAP cells.

The catalogue of differentially expressed proteins is reported in Table 1 with the following information: protein name, access number of Swiss-Prot database, protein abbreviated names, theoretical and experimental pI and $\mathrm{MW}$, identification methods, matched masses/searched masses ratio and number of peptide matches that covered the regions of the protein sequence.

These proteins were clustered into 9 functional categories, mainly according to the current ontology database [i.e. 24], with the abrogation of the redundancy. Proteins 

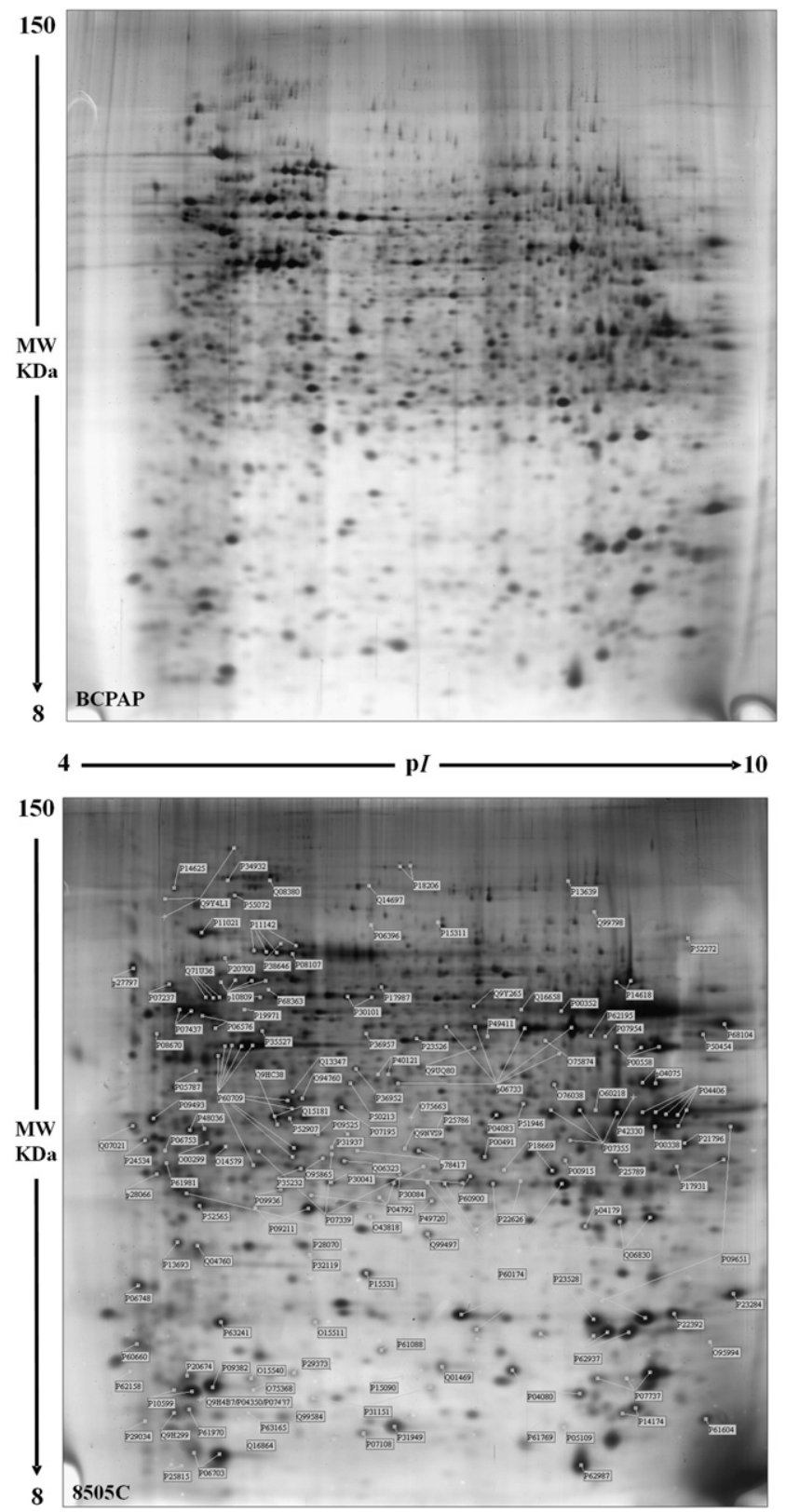

Fig. 3 - Representative 2D proteomic maps of BCPAP and 8505C cells. 2-DE separation was performed on IPG gel strips (18 cm, 3.5-10 NL) followed by the SDS-PAGE on a vertical linear-gradient slab gel (9-16\%T). Protein spots of known identity are labelled with the access number of the Swiss-Prot/TrEMBL database. When present, different isoforms of the same protein are jointly labelled.

with multifunctional activities were sorted according to their major function.

Fig. 4 shows the graphs illustrating the relative differences in density values (expressed as Vol\%) of protein spots from BCPAP (grey colour) and 8505C (black colour) cells. As shown, the two curves display significant divergences, at various degrees of amplitude in a number of proteins. Analytically, the nine protein classes are the following:

\subsubsection{Metabolic processes}

This class represents the most abundant among those identified in our system. It contains 17 protein forms corresponding to 12 isoforms of glycolitic enzymes, 2 mitochondrial proteins and 3 proteins of other metabolic processes. It is interesting the finding that all the identified glycolytic enzymes, including their isoforms, i.e.: ENOA, G3P, PGK1, KPYM, LDHA and TPIS, display a higher expression level in $8505 \mathrm{C}$ cells with respect to the BCPAP. These enzymes are key components of the glycolytic metabolism, but they are also involved in additional functions. Concurrently, the two proteins of the mitochondrial compartment, ECHM and VATF, appeared at lower intensity levels in the 8505C.

\subsubsection{Cytoskeleton and associated proteins}

This cluster includes 9 protein forms corresponding to 7 genes. Higher expression levels in 8505C regarded: COF1, PROF1, VINC, TBB5 and VIME, the latter almost absent in the BCPAP cells. In contrast, two epithelial markers, i.e. K1C9 and $\mathrm{K} 2 \mathrm{C} 8$, and an actin isoform displayed a lower intensity in 8505C than in BCPAP cells.

3.3.3. Membrane-associated proteins with multiple activities This group includes 4 protein forms. Three of which, LEG1, ANXA1 and ANXA2, showed higher expression levels in 8505C cells while a lower expression level was observed for the ANXA4.

\subsubsection{Calcium binding proteins}

Proteins within this cluster include 6 protein forms corresponding to 5 genes. Five of these proteins belong to the S100 family and four of them (two isoforms of S100P, S10A7 and S10AD) appeared less expressed in the $8505 \mathrm{C}$ cells, as did the calmodulin, a multifunctional calcium transducer; while the S10A6 appeared more expressed in 8505C cells.

\subsubsection{Regulators of cell proliferation}

This class includes 5 protein forms. All these proteins (MIF, NTF2, CCNH and SPB5), except AGR2, are characterized by higher expression levels in the 8505C cells.

\subsubsection{Molecular chaperones/heat shock proteins}

This group comprises 9 protein forms corresponding to 5 genes. It is interesting to note that all these proteins, including their isofoms (CH60, CH10, GRP75, HYOU1 and PDIA3) displayed lower expression levels in 8505C.

\subsubsection{Detoxification processes}

This class consists of 6 protein forms, four of which (AK1BA, 3HIDH, PRDX1, and AK1C3) were under-expressed, while two of them were highly expressed (LGUL and SODM) in 8505C cells. An altered expression of proteins of the antioxidant protective system has been also reported by other authors [25] in the poorly differentiated ARO cells (from anaplastic carcinoma) with respect to TPC-1 cells (from papillary carcinoma).

\subsubsection{Degradation machinery}

This cluster includes 3 protein forms: UCHL1 with a high expression level in $8505 \mathrm{C}$ cells, and two subunits of the proteosome (PSA1 and PSB4) showing lower expression levels. 


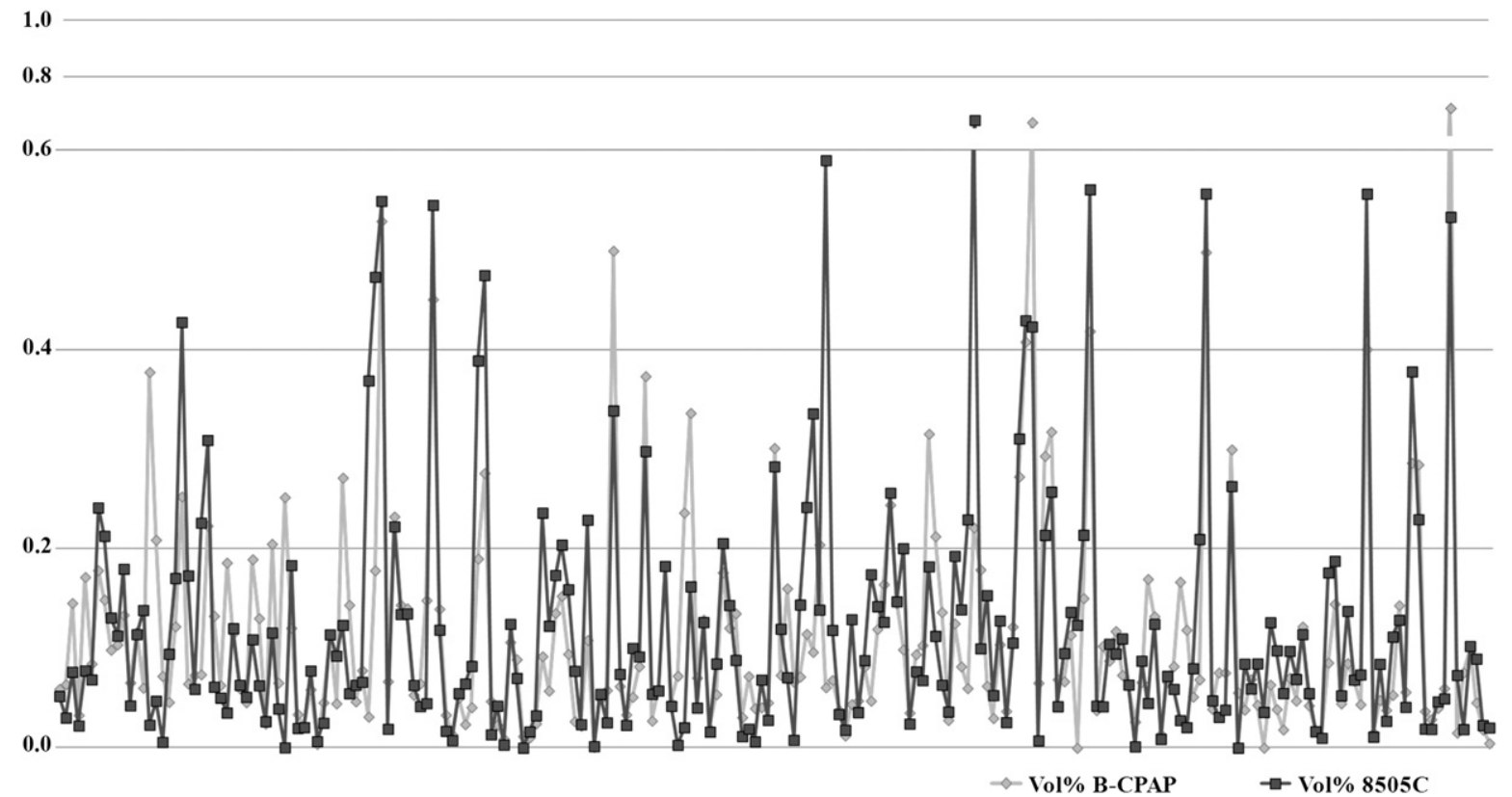

Fig. 4 - Global proteomic profiles of BCPAP and 8505C cells. The diagram shows the relative differences in density values (expressed as Vol\%) of protein spots from BCPAP (grey colour) and 8505C (black colour) cells. Each value is the mean of three independent determinations.

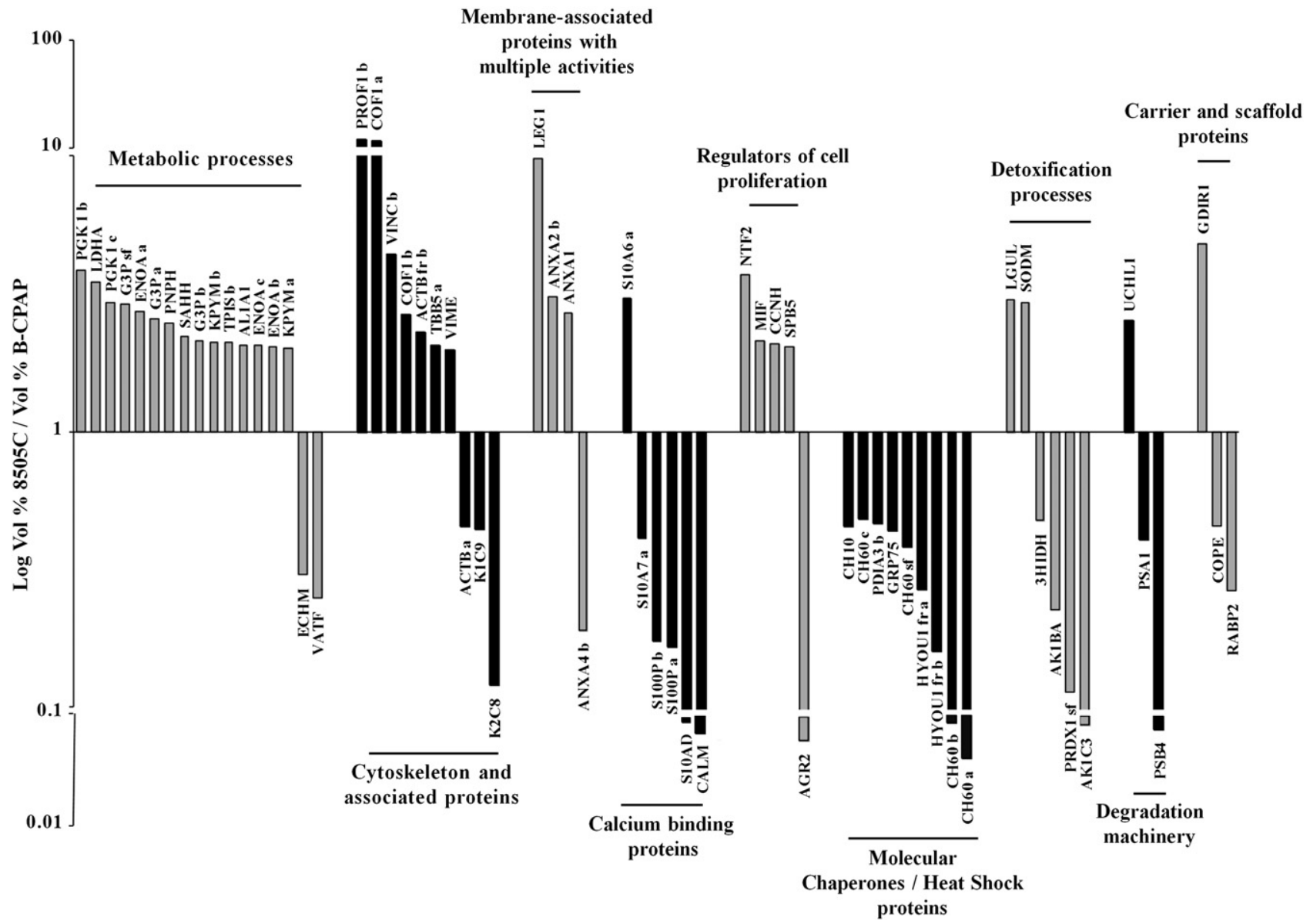

Fig. 5 - Histogram of differentially expressed proteins in BCPAP and 8505C cells, sorted in functional categories. Relative intensity of protein spots was calculated normalizing the data to the sum of all spot volumes on gels (Vol\%). Each value is the mean of three independent determinations. Vertical bars indicate Vol\% values. The protein levels were considered significantly different for $\geq 2$-fold change. The data in the graphs are expressed as mean number \pm SD. For protein symbols, see Table 1 . 
Table 1-Catalogue of the differentially expressed proteins in BCPAP and 8505C cell lines. Table reports the following information: Protein names, accession numbers (AC) and abbreviated names correspond to the nomenclature used in the Swiss-Prot database. The experimental values of $\mathrm{PI}$ and $\mathrm{MW}$ for every isoelectric spot were calculated with ImageMaster 2D Platinum system; the theoretical values represent the predicted MW and pI for each identified protein according to Swiss-Prot and TrEMBL database. Identification methods: 1, MALDI-TOF; 2, N-terminal sequencing by automated Edman degradation; and 3, Western Blotting.

Protein Name

\begin{abstract}
AC
\end{abstract}
Abbreviated Theor.

Theor. Exp.
Number$$
\text { Theor. Exp. }
$$$$
\text { Exp. ID }
$$$$
\%
$$$$
\%
$$$$
\text { Masses }
$$$$
\text { Sequence }
$$$$
\text { coverage (\%) }
$$
Matched $\mathrm{N}$-terminal residues

\begin{tabular}{|c|c|c|c|c|c|c|c|c|c|}
\hline $\begin{array}{l}\text { 3-hydroxyisobutyrate } \\
\text { dehydrogenase, mitochondrial }\end{array}$ & P31937 & 3HIDH & 35329 & 31290 & 8.38 & 5,62 & 1 & 23 & 21 \\
\hline \multirow[t]{2}{*}{ Actin, cytoplasmic 1} & P60709 & АСТВ a & 41737 & 42000 & 5.29 & 5,02 & 1,3 & 36 & 22 \\
\hline & & АСТВ fr b & & 37228 & & 5,37 & 1 & 21 & 34 \\
\hline $\begin{array}{l}\text { Anterior gradient protein } 2 \\
\text { homolog }\end{array}$ & 095994 & AGR2 & 19979 & 16224 & 9.03 & 8,83 & 1 & 27 & 50 \\
\hline $\begin{array}{l}\text { Aldo-keto reductase family } 1 \\
\text { member B10 }\end{array}$ & 060218 & AK1BA & 36020 & 36440 & 7,66 & 7,11 & 1 & 38 & 36 \\
\hline $\begin{array}{l}\text { Aldo-keto reductase family } 1 \\
\text { member C3 }\end{array}$ & P42330 & AK1C3 & 36853 & 37513 & 8.06 & 7,68 & 1 & - & 30 \\
\hline Retinal dehydrogenase 1 & P00352 & AL1A1 & 54862 & 50636 & 6.30 & 6,81 & 1 & 61 & 49 \\
\hline Annexin A1 & P04083 & ANXA1 & 38714 & 36053 & 6,57 & 6,48 & 1 & 46 & 52 \\
\hline Annexin A2 & P07355 & ANXA2 b & 38604 & 36440 & 7.57 & 6,88 & 1 & 50 & 15 \\
\hline Annexin A4 & P09525 & ANXA4 b & 35883 & 33134 & 5,83 & 5,71 & 1 & 36 & 64 \\
\hline Calmodulin & P62158 & CALM & 16838 & 13928 & 4.09 & 4,21 & 1 & 57 & 23 \\
\hline Cyclin-H & P51946 & $\mathrm{CCNH}$ & 37643 & 36945 & 6.73 & 6,61 & 1 & 48 & 38 \\
\hline $\begin{array}{l}10 \mathrm{kDa} \text { heat shock protein, } \\
\text { mitochondrial }\end{array}$ & P61604 & $\mathrm{CH} 10$ & 10932 & 10902 & 8.89 & 8,77 & 1 & 40 & 65 \\
\hline \multirow{4}{*}{$\begin{array}{l}60 \mathrm{kDa} \text { heat shock protein, } \\
\text { mitochondrial }\end{array}$} & P10809 & $\mathrm{CH} 60 \mathrm{a}$ & 61055 & 59065 & 5.70 & 5,00 & 1,2 & 28 & 26 , res. $33-38$ \\
\hline & & $\mathrm{CH} 60 \mathrm{~b}$ & & 59752 & & 5,08 & 1 & 78 & 39 \\
\hline & & $\mathrm{CH} 60 \mathrm{c}$ & & 59500 & & 5,17 & 2 & - & res $33-38$ \\
\hline & & CH60 sf & & 54488 & & 5,22 & 1 & 38 & 16 \\
\hline $\begin{array}{l}\text { Chloride intracellular channel } \\
\text { protein } 1\end{array}$ & O00299 & CLIC1 & 26923 & 31861 & 5.09 & 4,92 & 1 & 48 & 43 \\
\hline \multirow[t]{2}{*}{ Cofilin-1 } & P23528 & COF1 a & 18502 & 18547 & 8.22 & 6,30 & 1 & 45 & 61 \\
\hline & & COF1 b & & 18241 & & 7,08 & 1 & 100 & 52 \\
\hline Coatomer subunit epsilon & 014579 & COPE & 34482 & 31384 & 4,98 & 5,02 & 1 & 17 & 41 \\
\hline $\begin{array}{l}\text { Enoyl-CoA hydratase, } \\
\text { mitochondrial }\end{array}$ & P30084 & ECHM & 31387 & 27903 & 8.34 & 5,99 & 1 & 22 & 39 \\
\hline \multirow[t]{3}{*}{ Alpha-enolase } & P06733 & ENOA a & 47169 & 46541 & 7,01 & 6,22 & 3 & - & - \\
\hline & & ENOA $b$ & & 46541 & & 6,37 & 3 & - & - \\
\hline & & ENOA C & & 46201 & & 6,62 & 3 & - & - \\
\hline \multirow{3}{*}{$\begin{array}{l}\text { Glyceraldehyde-3-phosphate } \\
\text { dehydrogenase }\end{array}$} & P04406 & G3P a & 36053 & 36274 & 8.57 & 7,81 & 1 & 73 & 26 \\
\hline & & G3P b & & 36274 & & 8,01 & 2 & - & res. $2-11$ \\
\hline & & G3P sf & & 34355 & & 8,35 & 1 & 31 & 21 \\
\hline Rho GDP-dissociation inhibitor 1 & P52565 & GDIR1 & 23207 & 25087 & 5,01 & 4,87 & 1 & 23 & 38 \\
\hline $75 \mathrm{kDa}$ glucose-regulated protein & P38646 & GRP75 & 73681 & 74721 & 5.87 & 5,34 & 1 & 82 & 24 \\
\hline \multirow[t]{2}{*}{ Hypoxia up-regulated protein 1} & Q9Y4L1 & HYOU1 fr a & 111335 & 98292 & 5.16 & 4,62 & 1 & 56 & 14 \\
\hline & & HYOU1 fr b & & 13586 & & 4,62 & 1 & 40 & 12 \\
\hline Keratin, type I cytoskeletal 9 & P35527 & K1C9 & 62064 & 45528 & 5.14 & 5,23 & 1 & 18 & 11 \\
\hline Keratin, type II cytoskeletal 8 & P05787 & $\mathrm{K} 2 \mathrm{C} 8$ & 53704 & 39754 & 5.52 & 4,86 & 1 & 32 & 24 \\
\hline \multirow[t]{2}{*}{ Pyruvate kinase isozymes M1/M2 } & P14618 & KPYM a & 57937 & 59065 & 7.96 & 7,42 & 1 & 25 & 39 \\
\hline & & KPYM b & & 59500 & & 7,64 & 1 & 89 & 53 \\
\hline Galectin-1 & P09382 & LEG1 & 14716 & 12836 & 5.30 & 4,95 & 1 & 32 & 61 \\
\hline Lactoylglutathione lyase & Q04760 & LGUL & 65331 & 22454 & 5.12 & 4,86 & 1 & 24 & 31 \\
\hline $\begin{array}{l}\text { Macrophage migration inhibitory } \\
\text { factor }\end{array}$ & P14174 & MIF & 12476 & 11539 & 7.73 & 7,71 & 1 & 80 & 21 \\
\hline Nuclear transport factor 2 & P61970 & NTF2 & 14478 & 11457 & 5.10 & 4,82 & 1 & 37 & 53 \\
\hline Protein disulfide-isomerase A3 & P30101 & PDIA3 b & 56782 & 54488 & 5.98 & 5,85 & 1 & 57 & 27 \\
\hline \multirow[t]{2}{*}{ Phosphoglycerate kinase 1} & P00558 & PGK $1 \mathrm{~b}$ & 44615 & 41872 & 8.30 & 7,79 & 1 & 43 & 28 \\
\hline & & PGK $1 \mathrm{c}$ & & 41936 & & 8,06 & 1 & 67 & 13 \\
\hline Peroxiredoxin-1 & Q06830 & PRDX1 sf & 22110 & 22497 & 8.27 & 6,78 & 1 & 11 & 73 \\
\hline Profilin-1 & P07737 & PROF1 b & 15054 & 13442 & 8.44 & 7,57 & 1 & 23 & 56 \\
\hline Proteasome subunit alpha type-1 & P25786 & PSA1 & 29556 & 33335 & 6.15 & 6,17 & 1 & 100 & 34 \\
\hline Proteasome subunit beta type 4 & P28070 & PSB4 & 29204 & 23196 & 5.70 & 5,50 & 1 & 90 & 34 \\
\hline
\end{tabular}

(continued on next page) 
Table 1 (continued)

\begin{tabular}{|c|c|c|c|c|c|c|c|c|c|}
\hline Protein Name & $\begin{array}{c}\text { AC } \\
\text { Number }\end{array}$ & $\begin{array}{c}\text { Abbreviated } \\
\text { Name }\end{array}$ & $\begin{array}{l}\text { Theor. } \\
\text { MW }\end{array}$ & $\begin{array}{l}\text { Exp. } \\
\text { MW }\end{array}$ & $\begin{array}{c}\text { Theor. } \\
\text { pI }\end{array}$ & $\begin{array}{l}\text { Exp. } \\
\text { pI }\end{array}$ & $\begin{array}{l}\text { ID } \\
\text { methods }\end{array}$ & $\begin{array}{c}\% \\
\text { Masses } \\
\text { Matched }\end{array}$ & $\begin{array}{c}\text { Sequence } \\
\text { coverage }(\%) \\
\text { N-terminal residues }\end{array}$ \\
\hline $\begin{array}{l}\text { Cellular retinoic acid-binding } \\
\text { protein } 2\end{array}$ & P29373 & RABP2 & 15693 & 13829 & 5.38 & 5,41 & 2 & - & res. $1-10$ \\
\hline \multirow[t]{2}{*}{ Protein S100-P } & P25815 & $\mathrm{S} 100 \mathrm{P}$ a & 10400 & 51952 & 4,75 & 6,36 & 1 & 50 & 33 \\
\hline & & $\mathrm{S} 100 \mathrm{P} b$ & & 8625 & & 4,70 & 1 & 67 & 46 \\
\hline Protein S100-A6 & P06703 & $\mathrm{S} 10 \mathrm{~A} 6 \mathrm{a}$ & 10180 & 10786 & 5.32 & 4,39 & 1 & 100 & 28 \\
\hline \multirow[t]{2}{*}{ Protein S100-A7 } & P31151 & S10A7 a & 11471 & 9096 & 6.27 & 4,99 & 1 & 62 & 39 \\
\hline & & S10A7 b & & 12127 & & 5,52 & 1 & 35 & 35 \\
\hline Protein S100-A13 & Q99584 & S10AD & 11471 & 10484 & 5.90 & 5,96 & 1 & 33 & 44 \\
\hline Adenosylhomocysteinase & P23526 & $\mathrm{SAHH}$ & 47716 & 43728 & 5.92 & 6,07 & 1 & 14 & 30 \\
\hline $\begin{array}{l}\text { Superoxide dismutase }[\mathrm{Mn}] \text {, } \\
\text { mitochondrial }\end{array}$ & P04179 & SODM & 24722 & 23689 & 8.35 & 6,95 & 2 & - & res. $25-34$ \\
\hline Serpin B5 & P36952 & SPB5 & 42100 & 39936 & 5.72 & 5,76 & 1 & 21 & 27 \\
\hline Tubulin beta- 5 chain & P07437 & TBB5 a & 49671 & 51008 & 4.78 & 4,76 & 1 & 52 & 58 \\
\hline Triosephosphate isomerase & P60174 & TPIS b & 30791 & 26669 & 5.65 & 6,22 & 1 & 77 & 38 \\
\hline $\begin{array}{l}\text { Ubiquitin carboxyl-terminal } \\
\text { hydrolase isozyme L1 }\end{array}$ & P09936 & UCHL1 & 24824 & 26264 & 5.33 & 5,34 & 1 & 71 & 67 \\
\hline V-ATPase subunit F & Q16864 & VATF & 13370 & 10902 & 5.29 & 5,10 & 1 & 77 & 68 \\
\hline Vimentin & P08670 & VIME & 53652 & 44865 & 5,05 & 4,53 & 1 & 51 & 43 \\
\hline Vinculin & P18206 & VINC b & 123799 & 119845 & 5.50 & 6,04 & 1 & 25 & 30 \\
\hline
\end{tabular}

\subsubsection{Carrier and scaffold proteins}

This group includes 3 protein forms, GDIR1, RABP2 and COPE. A higher expression level was detected in 8505C cells for GDIR1, while RABP2 and COPE appeared under-expressed.

A diagram reporting the positive and negative variations of protein expression in logarithm scale and grouped by class is illustrated in Fig. 5.

\subsection{Cell motility}

Fig. 6 shows the sequential steps of the process of "healing" that both cell lines have undergone. Significant cell migration was seen at $6 \mathrm{~h}$ after the scratch only for the 8505C cells, with formation of cell protrusions and intercellular contacts at the wound margins. After $24 \mathrm{~h}$ the scratch was completely covered by the $8505 \mathrm{C}$ cells, differently from the BCPAP cells which appeared unable to cover the scratch by active migration.

\subsection{Gelatinolytic activity}

To verify the capability of cells to produce gelatinolytic enzymes, mainly MMP-2 and MMP-9, as potential invasivity markers, the conditioned media collected from BCPAP and $8505 \mathrm{C}$ cells respectively, were tested by gelatin zymography, performed after protein separation by mono-dimensional SDS-PAGE. Fig. 7(A) shows the results of a representative zymogram of BCPAP and $8505 \mathrm{C}$ conditioned media loaded with the same protein concentration (10 $\mathrm{g}$ /lane). BCPAP sample (lane 2) contained only two faint gelatinolytic bands corresponding to monomeric pro-MMP-9 (92 kDa) and pro-MMP-2 (72 kDa). On the contrary, 8505C sample (lane 3) showed a higher activity of the pro-enzymatic forms (pro-MMP-9 and pro-MMP-2), but also displayed a band corresponding to MMP-9 (86 kDa), co-migrating with immune-stained standards (Fig. 7(B)).

\section{Discussion}

Thyroid carcinomas are still an open field of studies because of their numerous histotypes and subtypes with unclear biological characteristics. In particular, studies of the thyrocyte and thyroid cancer proteomics, both ex vivo [26-29] and of cell lines [25] are in a minority compared with studies of the genome and transcriptome $[30,31]$.

In the present research we aimed at investigating proteomic and phenotypic properties that would increase the possibility to better characterize malignant forms of thyroid tumours. To this purpose, we performed a comparative analysis of two thyroid cancer cell lines, derived respectively from papillary (BCPAP) and anaplastic (8505C) thyroid carcinomas.

Observations at optical and scanning electron microscopes highlighted a large phenotypical diversity between the two cell lines. The BCPAP cells display a rather uniform cellular size, a regular cell shape and plasma membranes decorated by short microvillous expansions. Moreover, in most cases, cells at sub-confluence tend to form circular hollow structures which resemble the follicular structures of the gland. On the contrary, the $8505 \mathrm{C}$ cells display very irregular cellular morphology, they grow faster with propensity to overgrow in multilayer, and produce long cell surface protrusions of variable size, typical of very aggressive neoplastic cells [18].

Our proteomic analysis highlighted relevant differential expression of proteins and protein clusters, well matching with the cell behaviours of the two cell lines respectively.

Firstly, it is interesting to notice that the higher expression of proteins stimulating cell proliferation (CCNH, GDIR1 and MIF) [32-34] is detected in the 8505C cells showing higher growth rates than the BCPAP cells. Conversely a lower expression of proteins belonging to the folding control machinery may testify an impaired capability of the $8505 \mathrm{C}$ 

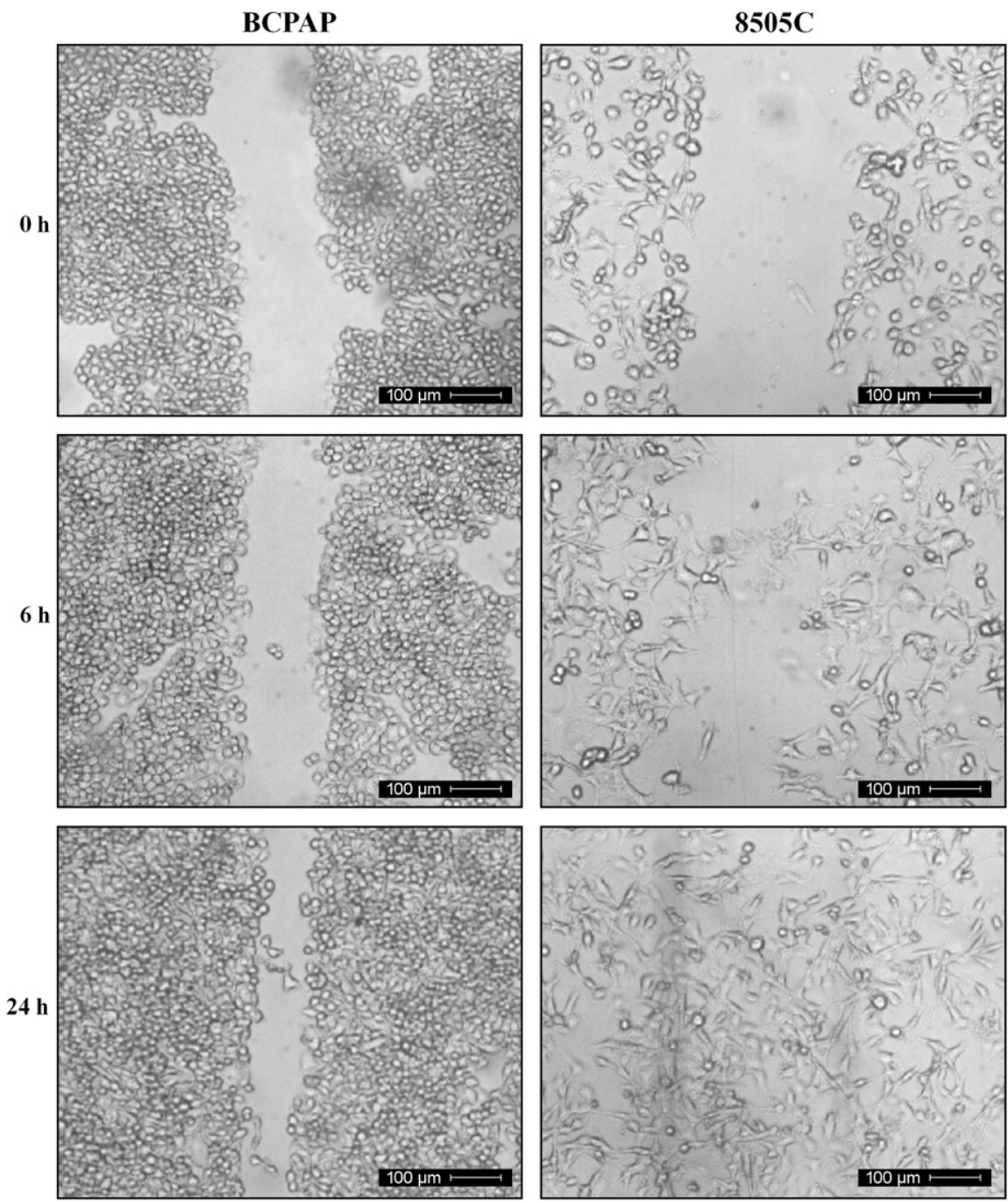

Fig. 6 - Migration of BCPAP and 8505C cells in a scratch wound assay. Panel shows the representative optical micrographs of B-CPAP and 8505C cells at $0 \mathrm{~h}, 6 \mathrm{~h}$ and $24 \mathrm{~h}$ from scratch (magnification: $10 \mathrm{x}$ ).

cells to perform differentiated cellular functions. An emblematic example is the decrement of the PDIA3, a protein that binds immature forms of thyroglobulin in the exocytosis and endocytosis pathways of thyrocytes, associated with hormonogenesis [35]. These results are in good agreement with the persistence of proliferative activities, in the absence of cell differentiation, as occurs in the anaplastic cancer.

Another significant property of most malignant tumours is the phenomenon of enhanced anaerobic metabolism, described as the "Warburg effect", which induces acidification of the cancer environment stimulating the development of a more aggressive and invasive phenotype. In our system we observed a higher amount of the glycolytic enzymes in $8505 \mathrm{C}$ cell line compared to the BCPAP, in agreement with the malignant properties of these cells. It is also relevant to recall that, in addition to the canonical functions, most glycolytic enzymes perform other cellular functions. For example, in some cases ENOA is expressed at the cell surface, where it may also act as a plasminogen receptor [36], thus mediating the activation of plasmin and consequent extracellular matrix degradation and cancer invasion. Similarly, the PGK1, another over-expressed glycolytic enzyme in the 8505C cells, may be secreted extracellularly by tumours. In these cases, it represents a critical target of the "chemokine axis" and an important regulator of the "angiogenic switch", essential for tumour growth and metastasis. In addition, PGK1 is known to regulate the E-cadherin/ $\beta$-catenin complex [37], suggesting that over-expression of this protein in tumours may promote decreased cell-cell adhesion and potentiate cell migration.

A differential expression of cytoskeleton proteins was also observed between the two cell lines, probably related with the observed alterations in the $8505 \mathrm{C}$ cell shape and polarity. In particular, the high expression level of COF1 in 8505C may have a role in the formation of membrane protrusions and directional spikes which are known to be associated with a motile and invasive phenotype [38]. Moreover, the COF1 plays a crucial role in the apoptotic process, as described in several researches $[39,40]$. In addition, the decreased expression of the epithelial markers K1C9 and K2C8, associated with the appearance of the mesenchymal marker VIME and with the 


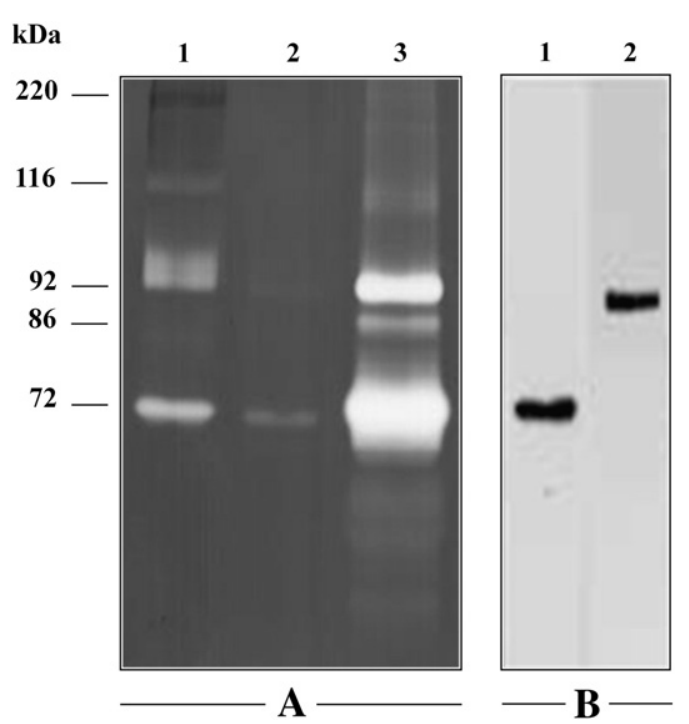

Fig. 7 - Detection of gelatinolytic activity. The figure displays: A) Representative gelatin zymogram $7.5 \%$ SDS-PAGE of conditioned medium samples from BCPAP (lane 2) and 8505C (lane 3) cells and serum sample (lane 1) used as molecular weight marker; and B) Western Blotting of purified gelatinases revealed with anti-MMP-2 (lane 1) and anti-MMP-9 (lane 2) monoclonal antibodies.

up-regulation of ANXA1, a protein involved in the membrane trafficking and TGF- $\beta$ signaling [41], may testify the occurrence of the epithelial-mesenchymal transition and the consequent acquisition of a more invasive and aggressive phenotype. Indeed, other proteins in the $8505 \mathrm{C}$ cell proteomics are described as associated with the tumour growth and metastatic progression: i.e. the S100A6 [42] and LEG1, which, among several functions, is also considered a co-promoter of MMP-2 and MMP-9 expression [43] and therefore an enhancer of tumour invasion and metastasis. In support of this hypothesis is the observation that the $8505 \mathrm{C}$ cells produce and release into the medium a significant quantity of matrix metalloproteinases MMP-2 and MMP-9.

\section{Conclusions}

The phenotypical features and in vitro behaviours of the BCPAP and $8505 \mathrm{C}$ cell lines, object of the present study, are indicative of the different malignant potentiality of the tumours from which the cells were derived. Indeed, the BCPAP cells display traits of well differentiated non-invasive cells, while the 8505C cells clearly show the expected characteristics of a very aggressive phenotype in vivo. The major features are: the exhibition of a high growth rate, the loss of the epithelial cell polarity, the transition from epithelial to mesenchymal cytoskeletal markers, the attitude to cell migration, as demonstrated by the scratch assay, the extension of long surface protrusion and cell membrane ruffling, the ability to produce matrix degrading enzymes (MMPs). Remarkably, the proteomic profiles are in agreement with phenotypical traits which characterize the two studied cell lines. These include: the over-expression of the glycolytic enzymes by the $8505 \mathrm{C}$ cells, which recall the in vivo Warburg effect typical of malignant tumours; the differential expression of cytoskeleton proteins, responsible for cell shapes and cell motility; the differential expression of many proteins responsible for cell proliferation, and others belonging to other functional classes. Finally, it is worth mentioning that the majority of the identified proteins are able to perform a variety of cellular functions, besides their canonical primary roles, that when deregulated may become instrumental for cancer growth and invasion. The differentially expressed proteins may be used for future applications as biomarkers of thyroid malignancy.

Supplementary data to this article can be found online at http://dx.doi.org/10.1016/j.jprot.2013.01.023.

\section{Acknowledgements}

The present work was supported in part by $\mathrm{PhD}$ funds to R.M. by the University of Palermo, and in part by $5 \times 1000$ State-made contributions to C.OB.S. for distinguished no-profit research associations.

\section{R E F E R E N C E S}

[1] Pellegriti G, De Vathaire F, Scollo C, Attard M, Giordano C, Arena S, et al. Papillary thyroid cancer incidence in the volcanic area of Sicily. J Natl Cancer Inst 2009;101:1575-83.

[2] Ain KB. Anaplastic thyroid carcinoma: Behavior, biology, and therapeutic approaches. Thyroid 1998;8:715-26.

[3] Takano T, Amino N. Fetal cell carcinogenesis: A new hypothesis for better understanding of thyroid carcinoma. Thyroid 2005;15:432-9.

[4] Lin RY. New insights into thyroid stem cells. Thyroid 2007;17: 1019-23.

[5] Mitsutake N, Iwao A, Nagai K, Namba H, Ohtsuru A, Saenko V, et al. Characterization of side population in thyroid cancer cell lines: Cancer stem-like cells are enriched partly but not exclusively. Endocrinology 2007;148:1797-803.

[6] Zito G, Richiusa P, Bommarito A, Carissimi E, Russo L, Coppola A, et al. In vitro identification and characterization of CD133(pos) cancer stem-like cells in anaplastic thyroid carcinoma cell lines. PLoS One 2008;3:e3544.

[7] Begum S, Rosenbaum E, Henrique R, Cohen Y, Sidransky D, Westra WH. BRAF mutations in anaplastic thyroid carcinoma: Implications for tumour origin, diagnosis and treatment. Mod Pathol 2004;17:1359-63.

[8] Nikiforova MN, Kimura ET, Gandhi M, Biddinger PW, Knauf JA, Basolo F, et al. BRAF mutations in thyroid tumours are restricted to papillary carcinomas and anaplastic or poorly differentiated carcinomas arising from papillary carcinomas. J Clin Endocrinol Metab 2003;88:5399-404.

[9] Nikiforov YE. Genetic alterations involved in the transition from well-differentiated to poorly differentiated and anaplastic thyroid carcinomas. Endocr Pathol 2004;15:319-27.

[10] Quiros RM, Ding HG, Gattuso P, Prinz RA, Xu X. Evidence that one subset of anaplastic thyroid carcinomas are derived from papillary carcinomas due to BRAF and p53 mutations. Cancer 2005;103:2261-8.

[11] Pucci-Minafra I, Cancemi P, Marabeti MR, Albanese NN, Di Cara G, Taormina P, et al. Proteomic profiling of 13 paired ductal infiltrating breast carcinomas and non-tumoral adjacent counterparts. Proteomics Clin Appl 2007;11:118-29. 
[12] Pucci-Minafra I, Cancemi P, Albanese NN, Di Cara G, Marabeti MR, Marrazzo A, et al. New protein clustering of breast cancer tissue proteomics using actin content as a cellularity indicator. J Proteome Res 2008;7:1412-8.

[13] Cancemi P, Di Cara G, Albanese NN, Costantini F, Marabeti MR, Musso R, et al. Large-scale proteomic identification of S100 proteins in breast cancer tissues. BMC Cancer 2010;10: 476.

[14] Paulin C, Fabien N, Fusco A, Pages MP, Patricot MC, Bornet H, et al. Description of a cell line arising from a human thyroid papillary carcinoma and synthesing the human chorionic gonadotropin hormone. C R Acad Sci III 1992;315:493-8.

[15] Ito T, Seyama T, Hayashi Y, Hayashi T, Dohi K, Mizuno T, et al. Establishment of 2 human thyroid-carcinoma cell-lines (8305c, 8505c) bearing p53 gene-mutations. Int J Oncol 1994;4: 583-6.

[16] Cancemi P, Albanese NN, DiCara G, Marabeti MR, Costantini F, Minafra S, et al. Multiple changes induced by fibroblasts on breast cancer cells. Connect Tissue Res 2010;51:88-104.

[17] Pucci-Minafra I, Minafra S, La Rocca G, Barranca M, Fontana S, Alaimo G, et al. Zymographic analysis of circulating and tissue forms of colon carcinoma gelatinase A [MMP-2] and B [MMP-9] separated by mono- and two-dimensional electrophoresis. Matrix Biol 2001;20:419-27.

[18] Pucci-Minafra I, Cancemi P, Di Cara G, Minafra L, Feo S, Forlino A, et al. Decorin transfection induces proteomic and phenotypic modulation in breast cancer cells 8701-BC. Connect Tissue Res 2008;49:30-41.

[19] Bradford MM. A rapid and sensitive method for the quantitation of microgram quantities of protein utilizing the principle of protein-dye binding. Anal Biochem 1976;72: 248-54.

[20] Cancemi P, Di Cara G, Albanese NN, Costantini F, Marabeti MR, Musso R, et al. Differential occurrence of S100A7 in breast cancer tissues: A proteomic-based investigation. Proteomics Clin Appl 2012;6:364-73.

[21] Pucci-Minafra I, Fontana S, Cancemi P, Alaimo G, Minafra S. Proteomic patterns of cultured breast cancer cells and epithelial mammary cells. Ann NY Acad Sci 2002;963:122-39.

[22] Pucci-Minafra I, Fontana S, Cancemi P, Basiricò L, Caricato S, Minafra S. A contribution to breast cancer cell proteomics: Detection of new sequences. Proteomics 2002;2:919-27.

[23] Fabien N, Fusco A, Santoro M, Barbier Y, Dubois PM, Paulin C. Description of a human papillary thyroid carcinoma cell line. Cancer 1994;73:2206-12.

[24] http://david.abcc.ncifcrf.gov/.

[25] Russo D, Bisca A, Celano M, Talamo F, Arturi F, Scipioni A, et al. Proteomic analysis of human thyroid cell lines reveals reduced nuclear localization of $\mathrm{Mn}$-SOD in poorly differentiated thyroid cancer cells. J Endocrinol Invest 2005;28:137-44.

[26] Ban Y, Yamamoto G, Takada M, Hayashi S, Ban Y, Shimizu K, et al. Proteomic profiling of thyroid papillary carcinoma. J Thyroid Res 2012;2012:815079.

[27] Sofiadis A, Becker S, Hellman U, Hultin-Rosenberg L, Dinets A, Hulchiy M, et al. Proteomic profiling of follicular and papillary thyroid tumors. Eur J Endocrinol 2012;166:657-67.
[28] Giusti L, Iacconi P, Ciregia F, Giannaccini G, Donatini GL, Basolo F, et al. Fine-needle aspiration of thyroid nodules: Proteomic analysis to identify cancer biomarkers. J Proteome Res 2008;7:4079-88.

[29] Braunschweig T, Kaserer K, Chung JY, Bilke S, Krizman D, Knezevic V, et al. Proteomic expression profiling of thyroid neoplasms. Proteomics Clin Appl 2007;1:264-71.

[30] Haugen BR, Duncan MW. Applications of proteomics to thyroid neoplasms: Are we there yet? Thyroid 2010;20:1051-2.

[31] Saiselet M, Floor S, Tarabichi M, Dom G, Hébrant A, van Staveren WC, et al. Thyroid cancer cell lines: an overview. Front Endocrinol (Lausanne) 2012;3:133.

[32] Kayaselcuk F, Erkanli S, Bolat F, Seydaoglu G, Kuscu E, Demirhan B. Expression of cyclin $\mathrm{H}$ in normal and cancerous endometrium, its correlation with other cyclins, and association with clinicopathologic parameters. Int J Gynecol Cancer 2006;16: 402-8.

[33] Zhao L, Wang H, Li J, Liu Y, Ding Y. Overexpression of Rho GDP-dissociation inhibitor alpha is associated with tumor progression and poor prognosis of colorectal cancer. J Proteome Res 2008;7:3994-4003.

[34] Meyer-Siegler KL, Leifheit EC, Vera PL. Inhibition of macrophage migration inhibitory factor decreases proliferation and cytokine expression in bladder cancer cells. BMC Cancer 2004;4:34.

[35] Mezghrani A, Courageot J, Mani JC, Pugniere M, Bastiani P, Miquelis R. Protein-disulfide isomerase [PDI] in FRTL5 cells. $\mathrm{pH}$-dependent thyroglobulin/PDI interactions determine a novel PDI function in the post-endoplasmic reticulum of thyrocytes. J Biol Chem 2000;275:1920-9.

[36] Redlitz A, Fowler BJ, Plow EF, Miles LA. The role of an enolase-related molecule in plasminogen binding to cells. Eur J Biochem 1995;227:407-15.

[37] Wang J, Wang J, Dai J, Jung Y, Wei CL, Wang Y, et al. A glycolytic mechanism regulating an angiogenic switch in prostate cancer. Cancer Res 2007;67:149-59.

[38] Wang W, Eddy R, Condeelis J. The cofilin pathway in breast cancer invasion and metastasis. Nat Rev Cancer 2007;7: 429-740.

[39] Chua BT, Volbracht C, Tan KO, Li R, Yu VC, Li P. Mitochondrial translocation of cofilin is an early step in apoptosis induction. Nat Cell Biol 2003;5:1083-9.

[40] Bernstein BW, Bamburg JR. ADF/cofilin: A functional node in cell biology. Trends Cell Biol 2010;20:187-95.

[41] de Graauwa M, van Miltenburga MH, Schmidtb MK, Ponta C, Lalaia R, Kartopawiroa J, et al. Annexin A1 regulates TGF- $\beta$ signaling and promotes metastasis formation of basal-like breast cancer cells. PNAS 2010;6:6340-5.

[42] Leśniak W, Słomnicki ŁP, Filipek A. S100A6-new facts and features. Biochem Biophys Res Commun 2009;390:1087-92.

[43] Wu MH, Hong TM, Cheng HW, Pan SH, Liang YR, Hong HC, et al. Galectin-1-mediated tumor invasion and metastasis, up-regulated matrix metalloproteinase expression, and reorganized actin cytoskeletons. Mol Cancer Res 2009;7:311-8. 